\title{
Types of Liability for Illegal Space Activities
}

\section{Iryna Ryzhenko}

\author{
Ph.D. in Law, Associate Professor, Kherson State University (Kherson, Ukraine) \\ E-mail: Rigenko_Irina@ukr.net \\ https://orcid.org/0000-0002-9208-2132
}

\section{Olena Halahan}

\author{
Senior lecturer, Kherson State Maritime Academy (Kherson, Ukraine) \\ E-mail: olena_halahan@ukr.net \\ https://orcid.org/0000-0001-8392-6965
}

The article analyzes the norms of international law, which relate to the responsibility of the state and other subjects of international law during the implementation of such types of space activities as remote sensing of Earth from outer space, provision of satellite broadcasting, prevention and elimination of emergency situations, the use of nuclear power sources in outer space. The issues of the international legal personality of the state in implementation of the applied types of space activities are researched; such forms of international legal responsibility of the state as political and material are considered. Particular attention is paid to a new stage of the development of space technologies. In this regard, in general, the national laws of some cosmic countries, which regulate the exploration of space both for the needs of science and for the needs of national defense of these countries, are analyzed. The study develops the idea of freedom of space, which cannot serve as a basis for the conduct of activities intended to breach the principle of respect for sovereignty, because the use of satellites may affect the sovereign rights and legitimate interests of other states. The issue of combining the principle of freedom of space activities with the principle of the sovereignty of states over their territory, particularly over natural resources, is considered. It is determined that the remote sensing of a foreign territory is a violation of the principle of sovereignty of countries, and may have a negative impact on developing countries. An analysis of the space laws of a number of countries makes it possible to conclude, that the current state of legal regulation of the international legal responsibility of countries on the effects of space activities is most often determined by the capabilities and the desire of countries to expand their own space activities and the desire to support private enterprises and their business related to space activities. Such research will contribute to the development of a systematic approach to the international legal regulation of the activities of States in the field of the registration of space station rent on the model of an office lease agreement, space tourism, extraction on asteroids, etc.

Keywords: international legal personality of the state, responsibility, applied types of space activities, compensation of losses, remote sensing of Earth, nuclear energy sources, satellite technologies, geostationary orbit, ownership of celestial bodies, Outer Space Treaty

Received: February 4, 2019; accepted: March 12, 2019

Advanced Space Law, Volume 3, 2019: 97-107.

https://doi.org/10.29202/asl/2019/3/8
(C) Ryzhenko, Irina, 2019
(C) Halahan, Olena, 2019 


\section{Introduction}

Nowadays, the whole world is aware of the importance of space as a source of prosperity and security [Rozin, 2017]. The question of the legal regulation of space activities has always been the subject of a study by a number of scientists, at the legislative level, space activity has been regulated by more than two dozen countries. Regarding the problem of the international legal personality of the state, and especially its responsibility for the consequences of space activities, this issue became the subject of not only legal but also political discussions, after which the relevant laws were created and various debates continued between representatives of space states. Legislation governing the space activities of countries has certain differences caused by their level of space industry development. The process of commercialization of space constantly requires decisive action not only from public law entities, but also from all other interested individuals and entities, therefore logically the question arises of expediency limiting the size of responsibility for the negative effects of the use of applied types of space activities, which in turn will contribute to the more active participation of private sector enterprises in it. In other words, the idea of a need to recover damages in case of accidents is becoming popular when the value of their size exceeds a certain amount.

The urgency of the article is due to the lack of comprehensive studies devoted to issues of international legal personality of the state in the field of the use of applied types of space activities. The questions of liability of subjects of international law for the negative consequences of the use of applied types of space activity are still insufficiently considered. At the same time, the analysis of a number of studies on the international legal regulation of the space industry shows that the cooperation of the states in this area has a rather serious background and legal basis, which includes a complex of conventions, agreements, covenants, developed both at the universal and regional levels.

The aim of the study is to carry out a comprehensive legal analysis of the state and prospects of the development of international law that relates to the responsibility of States and other international law subjects in the implementation of such applied space activities as remote sensing of the Earth from outer space, satellite broadcasting, prevention and elimination of emergency situations, the use of nuclear power sources in outer space.

\section{Presentation of the main material}

Space activities constantly accompany various kinds of risks, therefore, it is quite appropriate to ask questions, which are facing a number of cosmic countries: to continue to carry it out and to risk it deliberately or to restrict the existing state and use the existing property. In this context, a logical issue is important regarding the fundamental security function of the state, aimed at providing civil security. This state concern is manifested in the fact that by granting a permission to commercial organizations to engage in applied types of space activities, it should take care that in order to provide control and state supervision of the enterprises activities, which are engaged in launches of missiles and satellites into space, that a priori is already a source of increased danger. Historically, space exploration has undergone a series of stages. The first cosmic period took place in the period from 1957 to 1972 in conditions of rivalry between the US and the USSR, which led to the use of outer space for military purposes and to the first in the world history of landing man on the moon [von Bencke, 1997: 205]. During the second period, which took place from 1973 to about 1990, together with the European Space Agency, independent programs of space flight have already been developed 
by Japan, China, India and other countries, after which full-scale commercial use of outer space has already been deployed, in which private companies began to provide services for the launch and operation of artificial satellites for communications, broadcasting and remote sensing. The third space period began in 1990 and lasted until 2006, and was characterized by the emergence of compact spacecraft relatively low in value with significantly increased functionality, resulting in a sharp increase in the number of subjects of space activities, some of which began to provide space data processing services to those who does not have their own satellites [Von der Dunk, 2015: 38-43]. Nowadays humanity is in the fourth period of space development and the most important problems of legal regulation of the space industry are issues of international legal responsibility of the subjects of space industry [Setsuko, 2017].

The formation of the strategic space potential of the United States and China and the rapid rise in high-tech industries is similar to the situation that arose in connection with the launch of the first artificial satellite and the beginning of the space race between the US and the USSR, causing an increase in technological capabilities unattainable for others. Therefore, it is likely that the other countries lag behind in this competition, and this will create a problem that will affect their overall technological potential.

The basic rules of conduct in outer space are established by the Treaty on Principles Governing the Activities of States for the Exploration and Use of Outer Space, including the Moon and Other Celestial Bodies of 1967. Together with the freedoms of its research and use, the prohibition on the deployment of weapons of mass destruction, this document establishes special rules according to which the state has direct international responsibility for covering losses in the affected country and, on the basis of the licensing regime, should supervise the compliance by private enterprises with the norms provided by international law. National laws on space aim not only to ensure the legal regulation of space-based countries in space exploration for science, but also to promote the national defense of these countries.

Currently, space technology is developing extremely fast, and if it took at least five years to launch the satellite, now it takes just four months to prepare a mini-satellite. Actual problems remain, such as the fight against space debris and the rescue of astronauts who are in trouble. However, the present proposes to consider the following ambitious plans of modern space lawyers, which include the design of a space station lease according to the model of the office rental agreement, space tourism, mining on asteroids and the development of rules in contact with extraterrestrial life.

The question of the international legal personality of the state in space activities raises a number of discussions, since the 1967 Space Treaty is, in fact, the only truly international treaty, but it contains some legal gaps that allow some wishing even to claim heavenly bodies. In particular, in 1980, US resident Denis Hope sent a request to the United Nations, in which he announced his intention to assign the Moon. Denis Hope referred to the fact that the International Space Treaty states that each country can freely exercise its activities in outer space, however, it has been expressly forbidden to claim heavenly bodies to states, but the ban was not for private law subjects. As a result, the company of Hope received a multimillionprofit for selling plots on the moon to everyone who wishes. In an attempt to secure ownership of the purchased land for his clients, Hope even established the Democratic Republican Nation, the Galactic Government, in 2001, and in 2004 even prepared a constitution for it. Of course, Hope was not the only one who was willing to sell land on the moon, but he sued those who followed a similar business after him and won the case, but defending not ownership of the moon, but only copyright to the original idea. It is interesting to note that Hope was granted no 
authorization for the Moon, but he used the fact that he did not receive a response to his letter to the UN as tacit consent [International Law, 2018].

However, humanity has decided not to dwell on the idea of selling celestial bodies, and again, the citizens of the United States, the owners of the first "space travel agency" Space Adventures Ltd Peter Diamandis and Eric Andersen for the purpose of asteroid mining, founded the company Planetary Resources.

Therefore, it is logical to ask a question about the legality of claims to the asteroid by private companies, by analogy with the moon's appropriation by Denis Hope.

To answer this question, you should study the regulations of some countries that regulate their space activities. One of them is the Space Act, adopted by the United States in November 2015, which decided not to confine itself solely to space activities, but decided to go further by spreading its sovereignty over some of the space resources. It is a revolutionary fact that a national law grants US citizens the right to own, use, and manage (sell) the resources of celestial bodies and asteroids. This law also prohibits subjects of private law to possess the territories of celestial bodies. The United States decided to determine the ownership of celestial body resources, such as water and minerals independently, despite the fact that the International Space Treaty does not provide such a right for any country in the world. By adopting the Space Act, the United States has created the grounds for a legal conflict over whether anyone has to deal with the extraction, possession, and disposal of celestial bodies and asteroids rich in platinum, tungsten, iron, and nickel in general, and whether this right can be related to the sub-private law objects.

Therefore, the claims of private companies to heavenly bodies are still the subject of discussion. In this regard, the opinion of the professor of space law at the University of Nebraska - Lincoln France de Dr Dank on the question whether private companies are mining minerals on asteroids legally is interesting, which states: "Unfortunately", the 1967 Open Space Treaty leaves some doubts. Therefore, against the development of asteroids are protested by those who for some reason are negatively tuned. I adhere to the idea that this is legal, if the process is supervised by the relevant country, in this case, the United States" [Von der Dunk, 2018].

However, the United States is not the only state that has declared its intentions to seize the resources of heavenly bodies. The European Duchy of Luxembourg was the second largest country in the world that approved industrial production and the sale of space resources, in particular, the development of asteroids. So, on August 1, 2017, Luxembourg adopted a law that secured the legal status of extraction of minerals in space by private companies [Loi, 2017].

Space Act 2015 is the first step towards such regulation, and suggests considering it as an invitation to the international community to develop a global legal regime. Commenting on the fact that the Agreement declares that the open space does not belong to any of the states, he notes that on this occasion sometimes they conclude that the extraction of resources requires an international regime and international agreement, but it gives a rather interesting analogy that there is no state sovereignty in the open sea, but "this does not prevent anyone from fishing there".

Returning to the provisions of the 1967 Treaty, signed by more than 100 countries namely Art. 2, which states that Space, including the Moon and other celestial bodies, is not subject to national appropriation either through the proclamation of sovereignty on them, through the use or occupation, or by any other means, it is quite logical to think that that a space object or 
part thereof can not become a private property. However, the United States and Luxembourg, while taking laws on extraction of minerals in space, again took advantage of the gap in the 1967 Treaty, referring to the absence of provisions on extraction of minerals in space in it.

Following the United States, on November 16, 2016, Japan issued its own Space Act, which establishes the procedure for the issuance of permits for the launch by private companies of space rockets, as well as the use of satellites (hereinafter - the Law on Space Activities). The main idea of the law is that the mechanism of compensation for losses from the negative effects of space activities will function in the event that the amount of damage incurred in the event of accidents exceeds a certain amount provided for reimbursement.

Nowadays humanity is undergoing a new stage in the development of space technologies called New Space, where active development is taking place in the field of orbital transportation, flights to the Moon and Mars, space tourism and long-term human stay in space, as well as the development of space natural resources. Humanity sets itself the goal of creating an extremely branched "constellation" of artificial satellites to reach the entire planet, clearing the near-Earth space from garbage and debris, exploring and colonizing Mars, conducting exploration and development of natural resources on asteroids, and providing orbital supply and maintenance of effective resource extraction and space research. In this case, the qualitative and quantitative composition of the participants in space relations is constantly increasing, and since nobody can be insured from errors, the question of the responsibility of these entities and the reimbursement of losses to the affected parties remains actual [Kurasawa, 2018].

A major problem is also the ability to insure a private flight to space for organizations that are developing the direction of service of space tourists. Today, the only opportunity for those wishing to fly into space is to visit the International Space Station with Space Adventures Ltd and Roscosmos, but these services can only be paid by very wealthy customers. The idea is to reduce the cost of visits to space at the expense of suborbital tourist flights. But given that according to statistics 1 flight from 100 ends with an accident, companies are not able to prove the safety of these flights for passengers, what automatically creates the inability to insure such private flights into space.

To illustrate the relevance of this issue at our time, we quoted a specialist in International and Space Law, a Doctor of Law, a professor at the Department of Legal Studies at the University of Keio Aoki Setsuk, who commenting the Japan's law on space activities, states that "liability for damages in the event of an accident falls mainly on the launcher, even if the problem has occurred through a spacecraft, not a carrier rocket," while pointing out that this "will be able to increase the competitiveness of Japanese space launchers as it will inspire calm customers of space launchers - users of satellites from around the world". Aoki Setsuko notes that similar provisions are also in French law [Setsuko, 2017].

Compared with the other countries, Japan's space development was followed by another special scenario. In 1969, the Japanese parliament adopted the "Resolution on the peaceful use of space", according to which the Japanese space development was "only for peaceful purposes", which excluded the interaction of the forces of self-defense and nuclear energy with outer space, and it was assumed that they should be kept not only from research and development, but also from possession, management and use of space systems. For this reason, Japan's space development was carried out exclusively for civilian purposes. As for the use of space for defense purposes, only in the 1980s was approved the use of such services as communication and data transmission through commercial satellites. Thus, for a long time, national defense and space had no points of contact. 
All types of space activities are governed by the general norms of international space law. However, applications of space activity are of particular importance, which are characterized by the fact that satellites are not used for space exploration but have applied practical significance on the Earth. The necessity of international legal regulation of applied space activity is determined by the global nature of the consequences of these activities. The state shows its legal personality in the fact that it uses such satellites to solve practical problems of national economic activity [Von Bencke, 1997: 159].

It should be noted that the freedom of space can in no way serve as the basis for conducting activities that are aimed at violating the principle of respect for state sovereignty, since during the use of satellites can affect the sovereign rights and legitimate interests of other states [Doyle, 1992: 127].

That is why for the purpose of international legal regulation of applied types of space activity in the international space law a system of generally accepted principles and norms has been developed.

\section{The use of space assets for the study of Earth from space or remote sensing}

In 1986, the General Assembly of the United Nations adopted the Principles Concerning Remote Sensing of Earth from Outer Space, according to which States should promote the development of international cooperation in this field.

The problem of the use of information as a result of remote sensing from space appears on the basis of the principle of sovereignty of states over its natural resources.

The comprehensive use of the legal basis for the remote sensing of space activities is carried out both at the international and national levels. By means of remote sensing the interested subjects determine the state of the elements of land, the ocean and the atmosphere of the Earth, study the natural resources of the Earth, human-made objects and formations. The type of remote sensing is believed to be space control over compliance with arms limitation and disarmament treaties. The ability to take pictures of the earth's surface from outer space and to receive information about the earth's surface by processing the rays it has been exposed by satellite is causing the need for international legal regulation of activities, both from remote sensing of the Earth (RS) and from the use of remote sensing data.

The remote sensing procedure should be open and implemented on the basis of bilateral and multilateral agreements, according to which each state, the territory of which is subject to remote sensing, guarantees access to obtain information on its natural resources. States whose territory is to be explored from outer space may have access to the information first and foremost when they become widely known.

The issue of the permissibility of the transfer of information about individuals to a public authority and whether such information may be evidence in court is still pending. In the case of a positive response to this question, there could be a risk for the wide use of remote sensing to monitor citizens under the pretext of adhering to public order. It raises the question of ensuring access of citizens to the information accumulated on them through the use of remote sensing possibilities in administrative bodies. In this case, the necessary information on sensing should be considered as administrative information.

There is a need to improve international regulations governing space activities in the field of remote sensing. Such an important kind of activity as remote sensing requires more detailed 
legal regulation in order to prevent any abuse, to prevent damage to any state or international security or the natural environment of our planet.

Another problematic issue is the combination of freedom of space with the principle of State sovereignty over its territory, including over natural resources. RS of alien territory is a violation of the principle of sovereignty, and in particular may have negative consequences for developing countries.

It can be assumed that observation of people is possible by a court decision, if the results of remote sensing can be used as a result of evidence in order to prevent or disclose a crime.

As far as information obtained as a result of remote sensing is concerned, it is reasonable to regard it as intellectual property, which enables the owner of the indicated information to provide the necessary protection against its illegal copying and distribution. However, given the specifics of the market for remote sensing, this activity can simultaneously be engaged in subjects of both public and private law.

The important thing is that satellites of military surveillance are beyond the scope of the principles of remote sensing. So the state which are actively involved in space activities, if necessary, can always watch the satellite bases of observation in countries whose behavior is fearful. The subject of the regulation of the principles of remote sensing does not apply remote sensing areas of land and water surface, under the jurisdiction of the probe state. That is, the subject of the regulation of the principles of remote sensing is the territory of foreign states, as well as water and land spaces outside the national jurisdictions of the states. At the same time, the characteristic feature of space activity is that it is very difficult to distinguish exclusively military functions or only private legal relations in comparison with the most advanced technological branches. It is military development that often serves as a starting point for the development of applied types of space activities. For example, satellites of the GPS navigation system, providing positioning, navigating and timing tasks for the US Air Force, were designed to increase the accuracy of guiding combat missiles. However, nowadays, free GPS services are provided worldwide and used in the most important spheres of human life.

With regard to the responsibility of states in the field of remote sensing, then the relevant activities, being integral to the functional plan, depending on the city of occurrence is divided into terrestrial and space.

Space responsibility in the field of remote sensing is the direct responsibility of states for any national activity in outer space, regardless of what persons this activity is carried out.

As to the question of the regime of responsibility for ground-based remote sensing from outer space, it remains open. In particular, on the basis of Art. 6 of the 1967 Space Treaty, responsibility for both space and land-based remote sensing activities should be assigned to the state under whose jurisdiction this activity is being carried out.

When deciding the question of the nature of international legal responsibility in the field of remote sensing, its political and material forms are distinguished. The political responsibility for the operation of the remote sensing satellite, containing the distribution of satellite information on the international scene, will be borne by the states that authorize this activity and exercise control over it. Liability for losses incurred as a result of the transfer of information received to third parties should be assigned to national organizations and determined in accordance with the procedures adopted in national law and in private international law.

A serious problem arising in the course of implementing the remote sensing device is the clear delineation of the activity of satellite control over the observance of certain provisions concluded between the parties of agreements and spyware, intelligence activities, for which 
the perfect equipment of military satellites is used. Spyware (reconnaissance) activity is incompatible with the principles of space activity.

\section{Direct television broadcasting via satellites}

During the development of satellite technology, a technique was created that allowed the satellite to transmit a signal that could be received directly by individual television receivers and provide international direct television broadcasting. The need for legal regulation of the activities related to the implementation of international direct television broadcasting led to the adoption by the General Assembly of the United Nations in 1982 of the Principles of the Use of States of Artificial Satellites for International Direct Television Broadcasting. The role of the state, in accordance with the above-mentioned document, is that the service of international direct television broadcasting can be created only on the basis of agreements or arrangements between the state of broadcasting and the state of reception of broadcasts of international direct television broadcasting.

\section{Use of nuclear power sources in space law}

When discussing liability issues, it should be stressed that states have an international responsibility for all national activities, including those carried out using nuclear power sources in space. During interplanetary flights, as well as during flights in rather high orbits, nuclear power sources may be used.

The reason for this issue was the accident of the Soviet artificial satellite of the Earth "Kosmos-954", which resulted in radioactive contamination of the northern part of Canada in 1978. The reimbursement of losses incurred as a result of the use of nuclear power sources in space should cover the costs of conducting searches, evacuation and clearing of contaminated areas. States are liable for losses incurred as a result of the negative effects of the use of nuclear power sources in outer space [Cohen, 1984].

If the spent objects are stored at rather high orbits, nuclear energy sources can also be used during low-Earth orbits. Under all conditions, states should make efforts to protect people and the biosphere from radiological danger. The legal capacity of the state, which operates with the use of nuclear power sources in space, is that it conducts an expert assessment of the safety of nuclear energy sources before their launch into space, the results of which, prior to launch, should be published and communicated to the Secretary-General of the United Nations. The state also provides relevant information as a result of the danger of the return of radioactive materials to the Earth. In order to ensure the international legal regulation of the issue in 1992, the UN General Assembly adopted the Principles Concerning the Use of Nuclear Power Sources in Outer Space, based on the practical feasibility of using nuclear power sources aboard the space objects.

\section{Use of geostationary orbit}

Today, in the era of state-of-the-art technology, when some NASA lawyers are working on the issue of preparing agreements and reviewing the rules for contact of astronauts and extraterrestrial life, space lawyers are essentially dealing with legal regulation of satellites that are used to meet the needs of television, navigation, other commercial, military and government needs. In addition to the standard procedural issues arising from the current 
service of satellites, the problem of conflicts of States is required on the basis of a limited number of seats for these vehicles, in particular in the geostationary orbit. The conflict of interests is caused by the fact that the countries located at the equator believe that they have the right to control the sky over their territory. The problem requires an urgent solution, as there is a growing number of countries that want to launch their satellites into orbit, and the space for them is getting smaller. In this regard, the problem of legal relations between States and their legal personality are gaining increasing relevance in international law. This is especially true for applied types of space activities.

Thus, in accordance with the resolution of the UN General Assembly, one thousand seven hundred and twenty one (XVI) of December 20, 1961, communications with the help of satellites should become accessible to all countries of the world, what automatically means the exclusion of discrimination.

Parties wishing to launch their satellites into orbit refer to the provisions of the International Telecommunication Convention 1982, in which it is said that when using frequency bands for space radio communications members of the International Telecommunication Union take into account that the frequency and orbit of geostationary satellites are limited natural resources, which should be used efficiently and economically in order to ensure equitable access to this orbit and these frequencies, taking into account the special needs of countries, developing countries and the geographical situation of some countries. In order to prevent interference and effective functioning, the coordination of the operation of all satellite telecommunication systems is carried out within the framework of the International Telecommunication Union. The corresponding provision is duplicated in Art. 44 of the Statute of the International Telecommunication Union, adopted in 1992. And the United Nations Commission on Space has developed a draft General Principles, which ensure the equitable use of geostationary orbit by all countries now and in the future.

So, summing up the above-mentioned, we come to the conclusion that states must coordinate among themselves the directions of their space activity. Regardless of who carries out space activities — government agencies or non-state legal entities of the state, states will bear responsibility for violations of international space law. For the negative effects of space activities carried out by an international organization, responsibility will be borne both by the organization itself and by the participating countries. The procedure for the implementation of material liability is established by the Convention on International Liability for Damage Caused by Space Objects, 1972, which contains provisions for damages in the event of deprivation of life, bodily injury or other damage to health, destruction or damage to property of States, individuals or legal entities and international organizations.

In case if as a result of legitimate space activities, damage has been inflicted on a foreign state or its natural and legal persons, the obligation to compensate for damage will be encharged on the state which carries out or organizes the launch of the space object, as well as to the state from the territory or installations of which the object is launched. Responsibility in space law will be absolute in the event of damage on the surface of the Earth or an aircraft in flight. Responsibility for the damage caused by the space object of one state to the space object of another in any place, other than the Earth's surface, is based on the guilty principle.

Professor of Hokkaido University Suzuki Kazuto who received the "Santori" Award from the Humanities for his book "Space Development and International Politics" Thinking about the interconnection of space and the prospects of Japan's defense, believes that modern defense systems can not be imagined without the use of outer space, refers to space as a new territory 
of military clashes. Under those conditions, when there is a possibility to shoot the satellite directly from the earth's surface, the problem of legal regulation of possible intentional actions for the purpose of destruction of satellites becomes urgent. Thus, as far as possible, there is a probability between the developed cosmic powers that space systems may be the first objects of attack. In case of such an attack it is almost impossible to determine which party is the subject of the attack and what actually happens to the satellite devices of the injured party at the time of the attack. It is logical that the fact of physical attack on satellites and to determine the identity of the attacker is not a complicated task, but the situation looks quite different in the case of a cyberattack [Kazuto, 2018].

\section{Conclusions}

Thus, having analyzed the issues of the international legal personality of the state in the implementation of applied types of space activities, we arrive at a conclusion, that the state should ensure the protection of the environment, including the implementation of applied types of space activities. A state that intends to engage in space activities must meet the following criteria. Firstly, such a state should have approved national environmental standards, binding on all subjects of public and private law, consistent with environmental norms of international law. In addition, the state as a guarantor of national space activities should ensure that the procedure for compensating for the consequences of the space activities of its subjects is implemented. In this regard, each state should develop a system of national standards for the negative effects of space activities caused by its subjects. In order to avoid collisions, and due to the existence of different political will, it is extremely important to adopt a single unified statement on the international responsibility of the state for the negative consequences in the field of applied space activities caused by its own activities or activities of its subjects in the field. The said unified act should include a system of compensation for victims in the event that the negative consequences in the field of applied space activity will cause such a necessity. At the same time, the important point is that the damage can be caused both to the launching state and to any other person who has accidentally suffered from the consequences of activities related to space activities, subjects of another state, compensation for damage to the injured party should take place in full, regardless of the territoriality factor. There is no difference whether the damage was done to the population of its own country or to the representatives of another country. The rules for reimbursement of losses for the negative effects in the field of applied space activities should be regulated by a special kind of legislation — international agreements on the compensation of losses for the negative consequences of space activity, regardless of whether these losses were caused by deliberate actions of national subjects of space activity, whether the damage occurred in the result of official negligence. In contrast to the rules of private law, where responsibility often comes on the basis of confirmed intent or negligence, space law provides an absolute responsibility of the state for actions and inaction, both of its own or of its subjects. At the same time, in order to provide compensation for losses caused by the negative effects of space activities, national legislation should provide for a compulsory insurance against damage caused to third parties, regardless of whether space activities are carried out by public or private law of each particular country, since these losses must be reimbursed by the government of the country that carries out space activities and whether are going to be paid abroad or in the territory of that state. 
Private law subjects for the provision of space activities must have financial guarantees for the insurance of damages to the injured parties, while the states as public law entities, such as the United States, France and Japan, support the development of the industry with the participation of private investment in the following way: in case of damages that exceed the amount of the guarantee, governments make additional funds up to a certain amount set by the government. Governments which are interested in the technological development of the national space industry are always interested in attracting funding, including from entities of private law. And investment activity, as a rule, is livelier developing, in countries where the rules of business are clearly prescribed, and the proper legal regime is created. Analyzing the space laws of countries, we can conclude that the current state of legal regulation of the international legal responsibility of countries on the effects of space activities is most often determined by the capabilities and the desire of countries to expand this activity, firstly, and the desire to support private enterprises and their business related to space activities.

\section{References}

Cohen, Alexander F. Cosmos 954 and the International Law of Satellite Accidents. Yale Journal of International Law. Volume 10, 1984. https://digitalcommons. law.yale.edu/cgi/viewcontent.cgi?referer=https://scholar.google.com. ua/ \&httpsredir $=1 \&$ article $=1316 \&$ context $=$ yjil

Doyle, Stephen. Legal Aspects of Space Commercialization. Space Law: Development and Scope by Nandasiri Jasentuliyana. Praeger/International Institute of Space Law, 1992.

International Law: Contemporary Issues and Future Developments. Edited by Sanford Silverburg, Routledge, 2018.

Kazuto, Suzuky. Kosmos kak novaia terrytoryia voennukh stolknovenyi, 2018. https://www. nippon.com/ru/in-depth/a06101/

Kurasawa, Hideto. An overview of Japan's space activities. SpaceTech Asia, August 14, 2018. http://www.spacetechasia.com/an-overview-of-japans-space-activities/

Loi du 20 juillet 2017 sur l'exploration et l'utilisation des ressources de l'espace, 2017. http:// legilux.public.lu/eli/etat/leg/loi/2017/07/20/a674/jo

Rozin, Vadim M. Technology as a Time Challenge: Study, Concept and Types of Technology. Philosophy and Cosmology. Volume 19, 2017. http://ispcjournal.org/journals/2017-19/ Rozin_19.pdf

Setsuko, Aoki. New Law Aims to Expand Japan's Space Business, 2017. https://www. nippon.com/en/currents/d00294/new-law-aims-to-expand-japan\%e2\%80\%99s-spacebusiness.html

Von Bencke, Matthew. The Politics of Space: A History of U.S.-Soviet/Russian Competition and Cooperation in Space. Westview Press, 1997.

Von der Dunk, Frans. Handbook of Space Law. Edward Elgar Publishing Ltd., 2015.

Von der Dunk, Frans. Private Property Rights and the Public Interest in Exploration of Outer Space. University of Nebraska College of Law, 2018. https://doi.org/10.1007/s13752017-0271-9 